\title{
Pengaruh Pengembangan Sumber Daya Manusia Terhadap Kinerja Dosen dalam Meningkatkan Visi dan Misi Fakultas Ekonomi Universitas Serambi Mekkah
}

\author{
Zulfan YUSUF \\ Fakultas Ekonomi, Universitas Serambi Mekkah, \\ Jalan Batoh, Lueng Bata, Kota Banda Aceh, Provinsi Aceh, Indonesia \\ zulfanyusuf@serambimekkah.ac.id \\ SARBOINI \\ Fakultas Ekonomi, Universitas Serambi Mekkah, \\ Jalan Batoh, Lueng Bata, Kota Banda Aceh, Provinsi Aceh, Indonesia \\ sarboinise@serambimekkah.ac.id \\ Rika ARDIANA * \\ Fakultas Ekonomi, Universitas Serambi Mekkah, \\ Jalan Batoh, Lueng Bata, Kota Banda Aceh, Provinsi Aceh, Indonesia \\ rika.ardiana@gmail.com
}

\section{Article's history:}

Received 10 July 2021; Received in revised form 10 December 2021; Accepted 15 December, 2021; Published 30 December 2021. All rights reserved to the Lembaga Otonom Lembaga Informasi dan Riset Indonesia (KITA INFO dan RISET).

Suggested citation:

Yusuf, Z., Sarboini, S., Ardiana, R. 2021. Pengaruh Pengembangan Sumber Daya Manusia Terhadap Kinerja Dosen dalam Meningkatkan Visi dan Misi Fakultas Ekonomi Universitas Serambi Mekkah. JEMSI (Jurnal Ekonomi, Manajemen, dan Akuntansi), Volume 7 (2): 60-73. DOI: https://doi.org/10.35870/jemsi.v7i2.606.

\section{ABSTRAK:}

Tujuan penelitian ini adalah untuk menganalisa dan mengetahui apakah pengembangan sumber daya manusia berpengaruh terhadap terhadap kinerja dosen dalam menigkatkan visi misi Fakultas Ekonomi Universitas Serambi Mekkah Banda Aceh. Sampel dalam penelitian ini sebanyak 36 orang dari seluruh total populasi. Pengumpulan data menggunakan kuesioner, dan di analisa secara kualitatif dan kuantitatif. Analisis data untuk melihat pengaruh variabel terikat dengan variabel bebas menggunakan analisis persamaan regresi berganda. Uji hipotesis menggunakan uji statistik t-test, dengan bantuan program komputer program SPSS V.22 For Windows. Hasil penelitian diketahui bahwa hubungan antara faktor pengembangan sumber daya manusia $(X)$ dengan kinerja kinerja dosen $(\mathrm{Y})$ dalam menigkatkan visi misi Fakultas Ekonomi Universitas Serambi Mekkah, dapat diketahui dari nilai koefesien korelasi. Berdasarkan hasil analisis data diperoleh koefesien korelasi atau $\mathrm{R}$ sebesar 0,364. Keberartian dari koefesien korelasi tersebut dapat diuji dengan menggunakan uji-t. Berdasarkan hasil uji-t variabel independent berpengaruh terhadap kinerja dosen dalam menigkatkan visi misi Fakultas Ekonomi Universitas Serambi Mekkah sebesar $(2,281)$ dimana nilai thitung variabel tersebut tersebut lebih besar dari ttabel $(2,032)$. Koefisien determinasi (R2) sebesar 0,133 . Artinya sebesar $13,3 \%$ perubahan-perubahan kinerja dosen dapat dijelaskan oleh perubahan dalam faktor pengembangan sumber daya manusia $(X)$, sedangkan selebihnya yaitu sebesar $86,7 \%$, dipengaruhi oleh faktor-faktor variabel lain di luar daripada yang menjadi variabel penelitian ini, seperti pemberian insentif, gizi dan kesehatan, serta kondisi lingkungan sosial budaya dan faktor-faktor lain-lain yang dianggap sesuai untuk mempengaruhi kinerja dosen.

Kata Kunci: Pengembangan Sumber Daya Manusia; Kinerja Dosen.

JEL Classification: 015; E24. 


\section{PENDAHULUAN}

Pendidikan bagi kehidupan manusia merupakan kebutuhan mutlak yang harus dipenuhi sepanjang hayat. Tanpa pendidikan sama sekali mustahil suatu kelompok manusia dapat hidup berkembang sejalan dengan aspirasi (cita-cita) untuk maju, sejahtera dan bahagia menurut konsep pandangan hidup mereka. Perguruan tinggi sebagai penyelanggara pendidikan tinggi harus tampil sebagai leader yang dapat diandalkan mahasiswa dalam pengembangan dan peningkatan kualitas. Dengan demikian perguruan tinggi perlu menciptkan image yang menunjukkan kualitas dan karakteristik perguruan tinggi tersebut, sehingga akan mengarahkan pilihan dari para mahasiswa. Image dari perguruan tinggi dapat dilihat dari visi dan misinya, yang membedakanya dari perguruan tinggi lain. Visi dan misi merupakan acuan keunggulan mutu penyelenggaraan dan strategi perguruan tinggi untuk meraih masa depan. Strategi perwujudan visi dan misi harus dipahami dan didukung penuh komitmen serta partisipasi yang baik oleh para pemangku kepentingan. Visi didefinisikan sebagai kemampuan berpikir atau merencanakan masa depan dengan bijak dan imajinatif, menggunakan gambaran, mental tentang situasi yang dapat dan mungkin terjadi di masa mendatang (Yunus, 2016:32). Sedangkan misi merupakan rangkaian kegiatan utama yang harus dilakukan organisasi untuk mencapai visinya (Yunus, 2016:34).

Berkenaan dengan hal tersebut, maka dalam penelitian ini penulis memilih Fakultas Ekomomi Universitas Serambi Mekkah untuk menjadi tempat penelitian. Fakultas Ekomomi Universitas Serambi Mekkah sebagai perguruan tinggi penyelenggara pendidikan dibidang kependidikan yang merumuskan visi misinya untuk menampilkan ciri khasnya yang membedakan dengan perguruan tinggi lain. Visi Fakultas Ekonomi Universitas Serambi Mekkah pada tahun 2025 menjadikan Fakultas Ekonomi (FE) yang profesional, berkualitas dalam menghasilkan lulusan yang bertaqwa dan berakhlakul karimah dan mampu menjawab kebutuhan pasar tenaga kerja. Adapun misi yang diemban oleh Fakultas Ekonomi (FE) untuk menterjemahkan visi tersebut adalah sebagai berikut :

1. Melaksanakan pendidikan dan pengajaran yang berbasis ilmu pengetahuan dan keterampilan yang didukung dengan teori dan aplikasi yang relevan

2. Menyediakan peningkatan kapasitas dan kualitas layanan terbaik kepada dosen dan mahasiswa

3. Menertipkan administrasi akademik bagi mahasiswa dan dosen

4. Meningkatkan prasarana dan sarana yang berkualitas tinggi untuk menunjang proses pembelajaran yang efektif

5. Menghasilkan lulusan yang berkinerja baik dan kompetitif di dunia kerja dan masyarakat

6. Menyesuaikan kurikulum sesuai dengan dinamika pasar kerja

Selain itu, perguruan tinggi tidak hanya menciptakan image, namun juga membutuhkan pengembangan sumber daya manusia dan kinerja dosen yang bagus. Di mana pengembangan sumber daya manusia adalah sebuah proses yang dilakukan untuk mengembangkan pengetahuan, keahlian, dan kemampuan pekerjaan dengan kompetensi-kompetensi yang dikembangkan melalui pendidikan dan pelatihan untuk kepentingan peningkatan kinerja. Sedangkan kinerja dosen merupakan unjuk kerja yang ditunjukkan oleh dosen, baik secara kualitas dan kuantitas dalam melakukan tugasnya sesuai dengan tanggung jawab yang diberikan kepadanya, yang diukur berdasarkan kedisiplinan, kerjasama, loyalitas, dan kualitas kerja.

\section{TINJAUAN KEPUSTAKAAN}

Menurut Singodimedjo (dalam Sutrisno, 2009:61), mengemukakan pengembangan sumber daya manusia adalah proses persiapan individu-individu. untuk memikul tanggung jawab yang berbeda atau lebih tinggi di dalam organisasi, biasanya berkaitan dengan peningkatan kemampuan intelektual untuk melaksanakan pekerjaan yang lebih baik. Pengembangan mengarah pada kesempatan-kesempatan belajar yang didesain guna membantu pengembangan para pekerja. Dalam konteks sumber daya manusia, pengembangan dipandang sebagai peningkatan kualitas sumber daya manusia melalui program-program pelatihan, pendidikan. Apa yang dapat dijelaskan dari pengembangan sumber daya manusia adalah tentang developmental practice dan membutuhkan kolaborasi dengan program-program manajemen sumber daya manusia untuk mencapai hasil yang diinginkan. Pelatihan membantu karyawan dalam memahami suatu pengetahuan praktis dan pengetapannya, guna meningkatkan keterampilan, kecakapan, dan sikap yang diperlukan oleh organisasi dalam usaha mencapai tujuan (Sutrisno, 2009:62). 
Sedangkan pendidikan adalah suatu kegiatan untuk meningkatkan penguasaan teori dan keterampilan memutuskan terhadap persoalan-persoalan yang menyangkut kegiatan mencapai tujuan. Upaya ini dilakukan untuk memperbaiki kontribusi produktif para karyawan dan mengembangkan sumber daya manusia menghadapi segala kemungkinan yang terjadi akibat perubahan lingkungan. Arti dari pengembangan karyawan merupakan usaha-usaha untuk meningkatkan ketrampilan maupun pengetahuan umum bagi karyawan agar pelaksanaan pencapaian tujuan lebih efesien. Husnan (dalam Sutrisno, 2009: 62). Pengembangan sumber daya manusia tujuannya untuk meningkatkan kualitas profesionalisme dan keterampilan para karyawan dalam melaksanakan tugas dan fungsinya secara optimal. Dengan mengembangkan kecakapan karyawan dimaksudkan sebagai setiap usaha dari pemimpinan untuk menambah keahlian kerja tiap karayawan sehingga di dalam melaksanakan tugastugasnya dapat lebih efesien dan produktif. Oleh karena itu, organisasi perlu terus melakukan pengembangan sumber daya manusia karena investasi di dalam penngembangan sumber daya manusia merupakan pengeluaran yang ditunjukan untuk memperbaiki kapasitas produktif dari manusia. Dengan sumber daya manusia yang baik akan memiliki kekuatan kompetitif dan menjadi lebih sulit untuk ditiru sehingga sumber-sumber keberhasilan kompetitif, seperti teknologi proses produksi, proteksi pasar, akses terhadap sumber keuangan seharusnya lebih berdaya guna dan berhasil guna. Dengan memiliki kekuatan kompetitif diharapkan kinerja karyawan bisa terwujud. (Sutrisno, 2009:62). Menurut Husnan (dalam Sutrisno, 2009:63) mengemukakan pengembangan sumber daya manusia adalah proses pendidikan jangka panjang menggunakan prosedur sistematis dan terorganisasi, sehingga tenaga kerja manajerial mempelajari pengetahuan konseptual dan teoretis untuk tujuan umum. Pengembangan sumber daya manusia tujuannya untuk meningkatkan kualitas profesionalisme dan keterampilan para karyawan dalam melaksanakan tugas dan fungsinya secara optimal. Dengan mengembangkan kecakapan karyawan dimaksudkan sebagai setiap usaha dari pimpinan untuk menambah keahlian kerja tiap karyawan sehingga di dalam melaksanakan tugas-tugasnya dapat lebih efesien dan produktif. (Sutrisno, 2009: 63).

\section{Kinerja Dosen}

Pengertian kinerja merupakan hasil atau tingkat keberhasilan seseorang secara keseluruhan selama periode tertentu di dalam melaksanakan tugas dibanding dengan berbagai kemungkinan, seperti standar hasil kerja, target atau sasaran atau kriteria yang telah ditentukan terlebih dahulu dan telah disepakati bersama. Dalam kinerja tidak hanya hasil akhir dari sebuah pekerjaan, tapi bagaimana tahapan selama proses pekerjaan berlangsung apakah berjalan dengan baik sesuai dengan tujuan yang diharapkan. Menurut Nawawi (2012: 15) Kinerja adalah kemampuan yang dimiliki oleh individu dalam melakukan suatu pekerjaan, sehingga terlihat prestasi pekerjaannya dalam menggapai tujuan. Sementara menurut Subroto (2011:15) menyatakan bahwa kinerja dalam pembelajaran adalah kesanggupan atau kecakapan dosen dalam menciptakan suasana komunikasi yang edukatif anatara dosen dan mahasiswa yang mencakup segi efektif, kognitif dn psikomotorik sebagai upaya mempelajari sesuatu pengetahuan berdasarkan perencanaan sampai dengan tahap evaluasi dan tindak lanjut agar tercapai tujuan pengajaran secara efektif dan efesien. Sedangkan pengertian dosen adalah satu komponen ensensial dalam suatu sistem pendidikan di perguruan tinggi. Peran, tugas, dan tanggung jawab dosen sangat penting dalam mewujudkan tujuan pendidikan, yaitu mencerdaskan dan meningkatkan kualitas mahasiswa. Sementara Depdiknas (2005). Menyatakan dosen adalah pendidikan professional dan ilmuwan dengan tugas utama mentrasformasikan, mengembangkan dan menyebarluaskan ilmu pengetahuan, teknologi dan seni melalui pendidikan, penelitian dan pengabdian masyarakat. Dosen mempunyai kedudukan sebagai tenaga professional pada jenjang pendidikan tinggi yang diangkat sesuai peraturan perundang-undangan.

Depdiknas (2004), menyatkan kinerja dosen adalah kemampuan untuk melaksanakan pekerjaan atau tugas yang dimiliki dosen dalam menyelesaikan suatu pekerjaannya. Prestasi kerja atau penampilan kerja (performance). Kinerja atau performansi dapat diartikan sebagai presentasi kerja, pelaksanaan kerja, pencapaian kerja, hasil kerja atau unjuk kerja (LAN, 2004). Menurut Usman (2007:109) Kinerja dosen adalah unjuk kerja yang ditunjukkan oleh dosen, baik secara kualitas dan kuantitas dalam melakukan tugasnya sesuai dengan tanggung jawab yang diberikan kepadanya, yang diukur berdasarkan kedisiplinan, kerjasama, ketaatan, kehadiran, kompetensi professional, dan kualitas kerja. Berdasarkan pendapat diatas, bahwa kinerja akan mempengaruhi prestasi lembaga tempat dosen bertugas, sehingga dapat menimbulkan dorongan dalam dirinya untuk melaksanakan tugas dengan penuh tanggung jawab dan memberikan prestasi yang baik terhadap lembaga pendidikan tempat dosen bertugas. Pengukuran kinerja dosen harus dilakukan secara berkelanjutan memberikan umpan balik yang merupakan hal penting dalam upaya perbaikan secara terus menerus untuk mencapai keberhasilan lembaga pendidikan di masa mendatang. 


\section{Kerangka Pemikiran}

Berdasarkan pernyataan yang telah dikemukakan sebelumnya, penelitian ini bertujuan untuk mengetahui pengaruh yang terjadi antara variabel independen yaitu pengembangan sumber daya manusia terhadap variabel dependen yaitu kinerja dosen. Berikut ini dapat digambarkan kerangka pemikiran yang dijadikan dasar pemikiran dalam penelitian ini. Kerangka tersebut merupakan dasar pemikiran dalam melakukan analisis pada penelitian ini. Maka model kerangka pemikiran dapat dilihat pada Gambar dibawah:

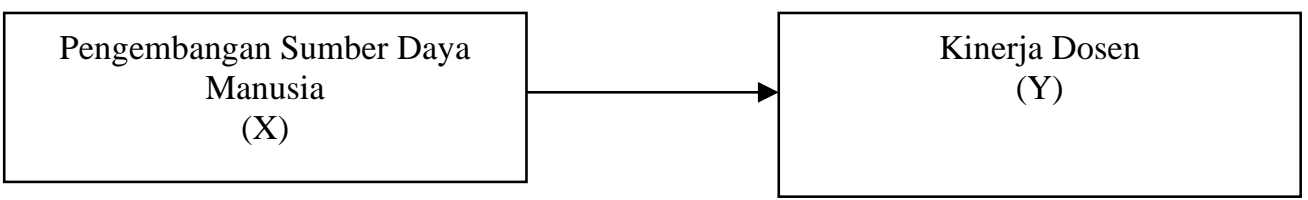

Gambar 1. Kerangka Pemikiran

\section{Hipotesis}

Hipotesis merupakan dugaan sementara atas suatu hubungan, sebab akibat dari kinerja variabel yang perlu dibuktikan kebenarannya (Hamid, 2010:16). Berdasarkan uraian yang pernah dihasilkan penelitian sebelumnya, maka dapat diformulasikan hipotesis dalam penelitian ini adalah: Di duga pengembangan sumber daya manusia secara parsial berpengaruh terhadap kinerja dosen dalam meningkatkan visi dan misi Fakultas Ekonomi Universitas Serambi Mekkah.

\section{METODE PENELITIAN}

\section{Lokasi dan Objek Penelitian}

Penelitian ini dilakukan pada Fakultas Ekonomi Universitas Serambi Mekkah yang beralamat di Jln. Tgk. Imum Lueng Bata, Panteriek, Kota Banda Aceh, Provinsi Aceh. Objek penelitian ini adalah pengaruh pengembangan sumber daya manusia terhadap kinerja dosen dalam meningkatkan visi dan misi Fakultas Ekonomi Universitas Serambi Mekkah.

\section{Populasi dan Sampel}

Populasi penelitian adalah keseluruhan objek penelitian atau objek yang diteliti. Populasi penelitian ini adalah seluruh dosen pada Fakultas Ekonomi Universitas Serambi Mekkah berjumlah 36 orang (Observasi pada Sekretaris Program Studi, Samsul Ikhbar, SE, MM). Sedangkan sampel penelitian adalah objek yang diteliti dan dianggap mewakili seluruh populasi. Tabel dibawah:

Tabel 1. Daftar Nama-Nama Dosen Program Studi Manajemen

Fakultas Ekonomi Universitas Serambi Mekkah

\begin{tabular}{|c|c|c|}
\hline No & Nama Dosen Tetap & Gelar Akademik \\
\hline 1 & $\begin{array}{l}\text { Saiful Amri } \\
\text { NIDN : } 0102057301\end{array}$ & SE,M.Si \\
\hline 2 & $\begin{array}{l}\text { Nasir } \\
\text { NIDN : } 0123086701\end{array}$ & SE,M.Si \\
\hline 3 & $\begin{array}{l}\text { Arsyad } \\
\text { NIDN : } 0131086701\end{array}$ & SE, M. Si \\
\hline 4 & $\begin{array}{l}\text { Badaruddin } \\
\text { NIDN : } 0124015601\end{array}$ & Drs, MDM \\
\hline 5 & $\begin{array}{l}\text { Sarboini } \\
\text { NIDN : } 0106077105\end{array}$ & SE,MM \\
\hline 6 & $\begin{array}{l}\text { M.Bakri } \\
\text { NIDN : } 0103016804\end{array}$ & SE,MM \\
\hline 7 & $\begin{array}{l}\text { Samsul lkhbar } \\
\text { NIDN : } 0121068301\end{array}$ & SE,MM \\
\hline
\end{tabular}




\begin{tabular}{|c|c|c|}
\hline 8 & $\begin{array}{l}\text { Fanny Nailufar } \\
\text { NIDN : } 0124098602\end{array}$ & SE,M. Si \\
\hline 9 & $\begin{array}{l}\text { llyas } \\
\text { NIDN : } 1305126901\end{array}$ & SE,MM \\
\hline 10 & $\begin{array}{l}\text { Susanti } \\
\text { NIDN : } 0105057701\end{array}$ & SE,M. Si \\
\hline 11 & $\begin{array}{l}\text { Nurfiani Syamsuddin } \\
\text { NIDN : } 1317017901\end{array}$ & SE,M. Si \\
\hline 12 & $\begin{array}{l}\text { Nelly } \\
\text { NIDN : } 0123018203\end{array}$ & SE,MM \\
\hline 13 & $\begin{array}{l}\text { ljal Fahmi } \\
\text { NIDN : } 0118078203\end{array}$ & SE,MM \\
\hline 14 & $\begin{array}{l}\text { Juwita } \\
\text { NIDN : } 0105036402\end{array}$ & SE,M. Si \\
\hline 15 & $\begin{array}{l}\text { Radhiana } \\
\text { NIDN : } 1320066701\end{array}$ & SE,MM \\
\hline 16 & $\begin{array}{l}\text { Zulfan Yusuf } \\
\text { NIDN : } 1331126502\end{array}$ & $\mathrm{SH}, \mathrm{MH}$ \\
\hline 17 & $\begin{array}{l}\text { Malahayati } \\
\text { NIDN : } 0120056804\end{array}$ & SE,MM \\
\hline 18 & $\begin{array}{l}\text { Kasmaniar } \\
\text { NIDN : } 0106098102\end{array}$ & SE,M. Si \\
\hline 19 & $\begin{array}{l}\text { Filia Hanum } \\
\text { NIDN : } 0112128301\end{array}$ & SE,M. Si \\
\hline 20 & $\begin{array}{l}\text { Mukhdasir } \\
\text { NIDN : } 0109026502\end{array}$ & SE,MM \\
\hline 21 & $\begin{array}{l}\text { Fitriliana } \\
\text { NIDN : } 1312057802\end{array}$ & SE,Mp \\
\hline 22 & $\begin{array}{l}\text { A. Hamid } \\
\text { NIDN : } 1319057101\end{array}$ & S.Ag.MA \\
\hline $\begin{array}{r}\text { Sumbe } \\
\text { Tab }\end{array}$ & $\begin{array}{l}\text { : Data Primer } 2019 \text { (Observasi) } \\
\text { el 2. Daftar Nama-Nama Dosen Program Studi Akur }\end{array}$ & tas Serambi Mekkah \\
\hline No & $\begin{array}{c}\text { Nama Dosen } \\
\text { Tetap }\end{array}$ & Gelar Akademik \\
\hline 1 & NIDN : 0108107105 & Dr.SE,M. Si \\
\hline 2 & NIDN : 0122017202 & Dr.SE,M. Si \\
\hline 3 & NIDN : 1320028701 & SE,M. Si \\
\hline 4 & NIRN $\cdot 1328047501$ & SE,M. Si \\
\hline 5 & NIDN : & SE,M. Si \\
\hline 6 & NIDN : 06087003 & SE,M. Si \\
\hline 7 & NIDN : 1302027701 & SE,M. Si \\
\hline 8 & NIDN : 1326018201 & SE,M. Si \\
\hline 9 & NIDN : 1324078301 & SE,M. Si \\
\hline
\end{tabular}




\begin{tabular}{llcc}
\hline 10 & NIDN : 1306037901 & Sufitrayanti & SE,M. Si \\
11 & NIDN : 0130038203 & Rita Nengsih & SE,M. Si \\
12 & NIDN : 1317087901 & Maryam & SE,M. Si \\
13 & NIDN : 1330018801 & Khairuna & SP, M. Si \\
14 & NIDN : 1320128701 & Cut Hamdiah & SE,M. Si \\
\hline Sumber : Data Primer 2019(Observasi) & &
\end{tabular}

Sumber : Data Primer 2019 (Observasi)

\section{Peralatan Analisis Data}

Dalam menganalisa data, untuk pengujian hipotensi yang diajukan digunakan metode kuantitatif yaitu dengan menggunakan peralatan statistik, sebagai peralatan analisis penelitian. Untuk melihat sejauh mana pengaruh pengembangan sumber daya manusia terhadap kinerja dosen dalam meningkatkan visi dan misi Fakultas Ekonomi Universitas Serambi Mekkah dilakukan dengan menggunakan alat ukur Regresi Linier Sederhana melalui bantuan perangkat SPSS (statistical product and service solution) yang dikemukakan oleh (Sugiyono, 2004:22) sebagai berikut :

Keterangan :

$$
Y=\alpha+\beta x+e
$$

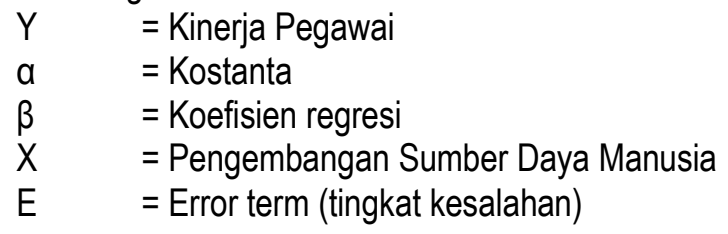

\section{Uji Validitas dan Reliabilitas \\ Uji Validitas}

Menurut Sugiyono (2012:121) uji validitas adalah hasil penelitian yang valid bila terdapat kesamaan antara data yang dikumpul dengan data yang sesungguhnya terjadi pada objek yang diteliti. Sebelum instrument penelitian digunakan untuk mengumpulkan data perlu dilakukan pengujian validitas. Hal ini digunakan untuk mendapatkan data yang valid dari instrument yang valid. Dalam penelitian ini, penentuan validitas dapat dilakukan dengan cari nilai korelasi skor masing-masing item skor dengan skor total item untuk setiap variable. Kemudian nilai $r_{\text {hitung }}$ yang diperoleh dari korelasi tersebut dibandingkan dengan nilai $r_{\text {tabel }}$ pada tingkat keyakinan 95 persen.

\section{Uji Reliabilitas}

Menurut Sugiyono (2012:121) uji reliabilitas adalah instrument yang bila digunakan beberapa kali untuk mengukur objek yang sama, akan menghasilkan data yang sama. Setelah instrument diuji validitasnya maka langkah selanjutnya yaitu menguji reabilitas. Adapun menurut Ghozali (2011:48) pengukur reliabilitas dapat dilakukan dengan dua cara yaitu :

1. Repeated Measure atau pengukuran ulang: disini seorang akan disodori pertanyaan yang sama pada waktu yang berbeda,dan kemudian dilihat apakah ia tetap konsisten dengan jawaban.

2. One Shot atau pengukuran sekali saja: disini pengukurannya hanya sekali dan kemudian hasilnya dibandingkan dengan pertanyaan. SPSS memberikan fasilitas untuk mengukur reliabilitas dengan uji statistic Cronbach Aplha ( $\alpha$ ).

Dalam penelitian ini menggunakan pengukuran reliabilitas cara kedua yaitu One Shot atau pengukuran sekali saja. Pengukuran reliabilitas dalam penelitian dibantu dengan SPSS untuk uji statistic Cronbach Aplha (a) akan menentukan instrument yang digunakan dalam penelitian ini reliabilitas digunakan atau tidak. 


\section{Uji Asumsi Klasik \\ Uji Normalitas}

Menurut Santoso (2007:258) uji normalitas digunakan untuk menguji data yang diperoleh berdistribusi normal atau tidak, hal ini dapat dilakukan dengan melihat sebaran standardized pada kurva p-plots, bila standardized residual berapa pada kisaran garis normal, maka data mempunyai ditribusi normal. Selanjutnya sebagai pertimbangan dalam menentukan statistic yang cocok untuk pengujian hipotesis. Apabila data berdistribusi normal, maka digunakan statistic parametric, sebaliknya apabila tidak berdistribusi normal, maka digunakan statistic non parametric.

\section{HASIL PENELITIAN DAN PEMBAHASAN}

\section{Hasil Uji Validitas dan Reliabilitas Uji Validitas}

Pengujian validitas data dalam penelitian ini dilakukan secara statistik yaitu dengan menggunakan uji Pearson Product Moment Coefficient of Correlation dengan bantuan program Statistical Product and Service Solution (SPPS) versi 20.0. Berdasarkan out-put komputer (out-put SPSS), nilai korelasi yang diperoleh masingmasing pernyataan dibandingkan dengan nilai kritis korelasi product moment di mana hasilnya menunjukkan bahwa semua pernyataan mempunyai nilai korelasi di atas nilai kritis $5 \%$ yaitu di atas 0.329 (lihat Tabel Nilai Kritis Korelasi r Product-Moment untuk n $36-2=0.329$ pada output SPSS), sehingga pernyataan-pernyataan tersebut adalah signifikan dan memiliki validitas konstruk. Ini berarti data yang diperoleh adalah valid dan dapat dipergunakan untuk penelitian. Untuk lebih jelasnya dapat dilihat pada tabel berikut ini:

Tabel 3. Hasil Uji Validitas

\begin{tabular}{|c|c|c|c|c|}
\hline Butir Pernyataan & Variabel & r hitung & $r$ tabel & Status \\
\hline Item 1 & \multirow{5}{*}{$X$} & 0.588 & 0.329 & Valid \\
\hline Item 2 & & 0.446 & 0.329 & Valid \\
\hline Item 3 & & 0.453 & 0.329 & Valid \\
\hline Item 4 & & 0.464 & 0.329 & Valid \\
\hline Item 5 & & 0.606 & 0.329 & Valid \\
\hline Item 1 & \multirow{6}{*}{$Y$} & 0.427 & 0.329 & Valid \\
\hline Item 2 & & 0.510 & 0.329 & Valid \\
\hline Item 3 & & 0.425 & 0.329 & Valid \\
\hline Item 4 & & 0.421 & 0.329 & Valid \\
\hline Item 5 & & 0.511 & 0.329 & Valid \\
\hline Item 6 & & 0.443 & 0.329 & Valid \\
\hline
\end{tabular}

Sumber : Data Primer 2019 (diolah)

Berdasarkan tabel 3 dapat dijelaskan bahwa semua variabel yang digunakan dalam penelitian ini dinyatakan valid, sehingga semua pertanyaan yang terkandung dalam kuesioner penelitian ini dinyatakan valid untuk dilanjutkan ke penelitian yang lebih mendalam, karena diperoleh nilai validitas lebih besar dari nilai kritis product moment sebesar 0.329 pada tingkat signifikansi $\square=5 \%$, sehingga instrumen data tersebut layak untuk dilakukan pembahasan lebih lanjut.

\section{Uji Reliabilitas}

Untuk menilai kehandalan kuesioner yang digunakan, maka dalam penelitian ini menggunakan uji reliabilitas, yaitu berdasarkan Cronbach Alpha. Analisis ini digunakan untuk menafsirkan korelasi antara skala yang dibuat dengan skala variabel yang ada. Malhotra (2015:268) menyatakan, koefisien atau nilai Cronbach alpha yang dapat diterima di atas 0,60 . Untuk lebih jelas besarnya nilai alpha pada masing-masing variabel diperlihatkan pada tabel berikut ini:

Tabel 4. Reliabilitas Variabel Penelitian (Alpha) 


\begin{tabular}{clccc} 
NNo & \multicolumn{1}{c}{ Variabel } & Nilai Alpha & Kriteria & Status \\
\hline 1. & Pengembangan SDM $(\mathrm{X})$ & 0.750 & 0.60 & Reliable \\
2. & Kinerja Dosen $(\mathrm{Y})$ & 0.725 & 0.60 & Reliable \\
\hline
\end{tabular}

Sumber : Data Primer 2019 (diolah)

Uji reliabilitas terhadap 2 (dua) atribut dalam variabel pengembangan sumber daya manusia $(X)$ dan kinerja dosen $(Y)$ di Fakultas Ekonomi Universitas Serambi Mekkah sebagaimana yang diperlihatkan pada tabel 4.3 diperoleh nilai alpha masing-masing sebesar 0.750 dan 0.725 , dengan demikian nilai dari atribut yang terlibat dalam pengukuran variabel tersebut memenuhi kredibilitas Cronbach's Alpha karena nilai alpha melebihi dari 0,60.

\section{Uji Asumsi Klasik \\ Uji Normalitas}

Pengujian asumsi normalitas untuk menguji data variabel bebas $(X)$ dan variabel terikat $(Y)$ pada persamaan regresi yang dihasilkan, apakah berdistribusi normal atau berdistribusi tidak normal. Jika distribusi data normal, maka analisis data dan pengujian hipotesis digunakan statistik parametrik. Pengujian normalitas data menggunakan uji kolmogorov-smirnov one sampel test dengan kriteria uji: jika probabilitas signifikan $>0,05$ maka data berdistribusi normal. Pengolahan data dalam penelitian ini memperoleh hasil sebagai berikut:

Tabel 5. Uji Normalitas

\begin{tabular}{cc} 
Normalitas & Residual \\
\hline Kolmogorov-Smirnov Z & 0,168 \\
Sig. & 0,117 \\
\hline
\end{tabular}

Berdasarkan tabel di atas dapat dilihat bahwa nilai signifikan dari variabel-variabel penelitian adalah sebesar 0,117 . Hal ini berarti nilai signifikansi tersebut lebih besar dari nilai $\square(0,05)$, ini berarti seluruh data berdistribusi normal. Selain itu, dasar pengambilan keputusan uji normalitas lainnya juga dilakukan berdasarkan grafik histogram dan grafik p-plot. Adapun dasar pengambilan keputusannya adalah sebagai berikut:

1. Data dikatakan berdistribusi normal, jika data menyebar disekitar garis diagonal dan mengikuti arah garis diagonal atau grafik histogramnya.

2. Sebaliknya data dikatakan tidak berdistribusi normal, jika data menyebar jauh dari arah garis dan tidak mengikuti diagonal grafik histogramnya.

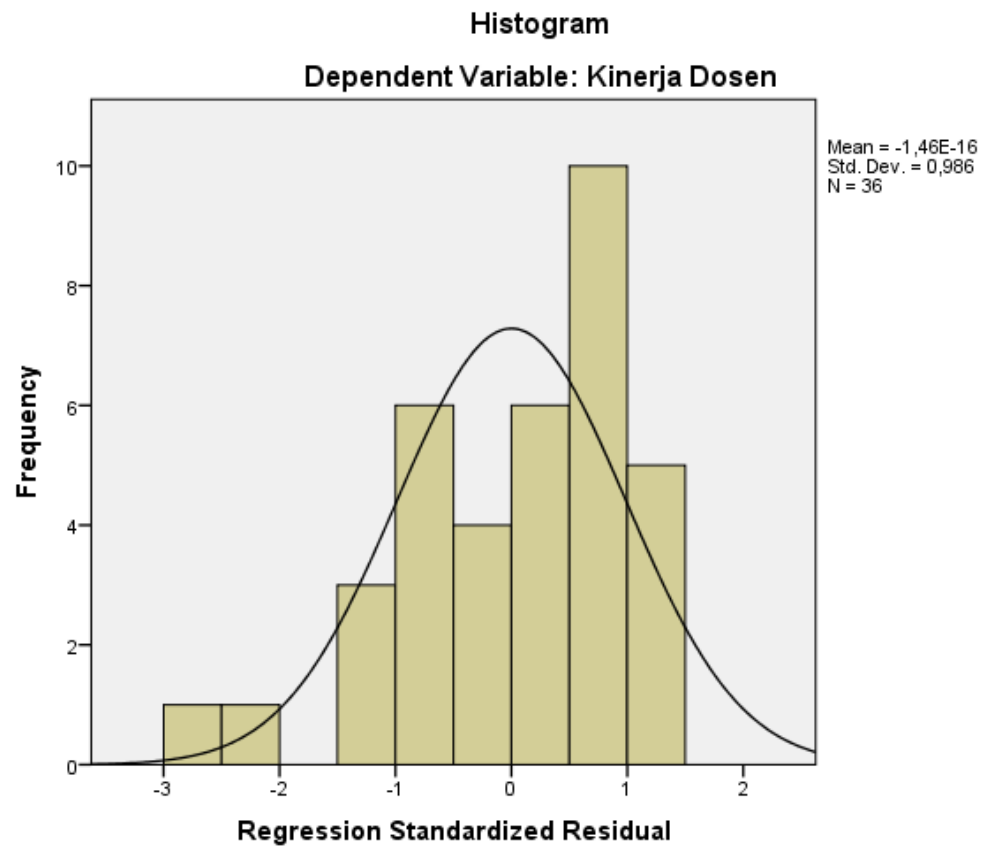

Gambar 2. Histogram Uji Normalitas 


\section{Uji Multikolonieritas}

Uji asumsi klasik ini digunakan untuk mengukur tingkat asosiasi (keeratan) hubungan/pengaruh antar variabel bebas tersebut melalui besaran koefisien korelasi (r). Pedomam pengambilan keputusan pada uji multikolonieritas dengan mengguna-kan SPSS adalah dengan melihat nilai tolerance dan nilai VIF, yaitu:

A. Berdasarkan nilai tolerance

1. Jika nilai tolerance lebih besar dari 0,10 maka artinya tidak terjadi multikolonieritas dalam model regresi

2. Jika nilai tolerance lebih kecil dari 0,10 maka artinya terjadi multikolonieritas dalam model regresi.

B. Berdasarkan nilai VIF

1. Jika nilai VIF lebih kecil dari 10,00 maka artinya tidak terjadi multikolonieritas dalam model regresi

2. Jika nilai VIF lebih besar dari 10,00 maka artinya terjadi multikolonieritas dalam model regresi.

Tabel 6. Uji Asumsi Klasik Multikolinieritas

\begin{tabular}{|l|c|c|}
\hline \multirow{2}{*}{ Variabel } & \multicolumn{2}{|c|}{ Kolonieritas } \\
\cline { 2 - 3 } & Tolerance & 1.000 \\
\hline Pengembangan SDM & 1.000 & VIF \\
\hline
\end{tabular}

Berdasarkan hasi output uji multikolonieritas di atas, dapat dilihat bahwa nilai tolerance keseluruhan variabel lebih besar dari 0.10 , dan nilai VIF dari keseluruhan variabel lebih kecil dari 10.00. Dengan demikian, mengacu pada dasar pengambilan keputusan uji multikolonieritas di atas, dapat disimpulkan bahwa tidak terjadi gejala multikolonieritas pada keseluruhan variabel tersebut.

\section{Uji Heteroskedastisitas}

Dalam persamaan regresi linier sederhana perlu diuji sama atau tidak varians dari residual dari observasi yang satu dengan observasi lainnya. Jika residual mempunyai varians yang sama, disebut homoskedastisitas. dan jika tidak sama disebut heteoskedastisitas. Persamaan regresi yang baik jika tidak terjadi heteroskedastisitas. Analisis uji ini menggunakan SPSS melalui grafik scatterplot antara Z prediction (ZPRED) untuk variabel bebas (sumbu $X=Y$ hasil prediksi) dan nilai residualnya (SRESID) merupakan variabel terikat (sumbu $Y=Y$ prediksi $-Y$ rill). Homoskedastisitas terjadi jika titik-titik hasil pengolahan data antara ZPRED dan SRESID menyebar di bawah ataupun di atas titik origin (angka 0 ) pada sumbu $Y$ dan tidak mempunyai pola yang tertentu. Hasil olah data untuk uji homoskedastisitas tersebut dapat dilihat pada grafik berikut ini:

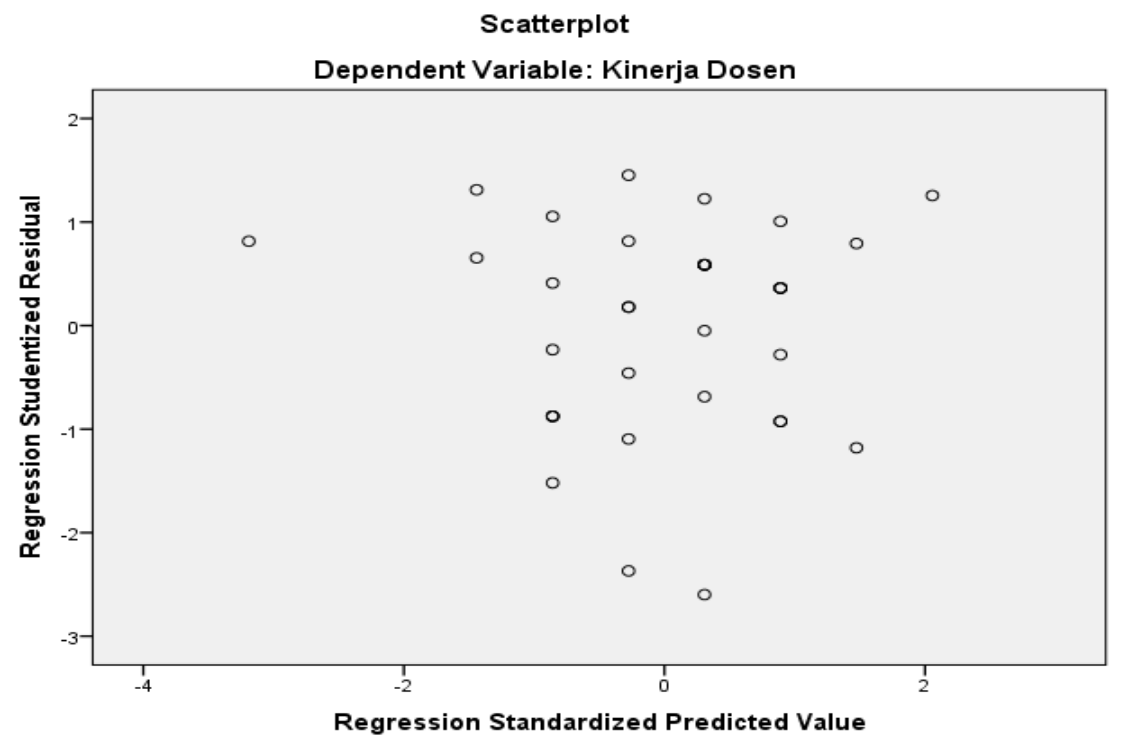

Gambar 3. Scatterplot Plot Uji Normalitas Heteroskedastisitas 
Dari hasil output gambar scatterplot di atas, didapat titik-titik menyebar di bawah serta di atas sumbu Y, dan tidak mempunyai pola yang teratur. Maka dengan demikian dapat dapat disimpulkan bahwa variabel bebas di atas tidak terjadi heteroskedastisitas atau bersifat homoskedastisitas. Uji heteroskedastisitas digunakan untuk mengetahui apakah terjadi penyimpangan model karena gangguan varian yang berbeda antar observasi satu ke observasi lain. Pengujian heteroskedastisitas dilakukan dengan mengamati grafik scatter plot pada output SPSS, menurut Duwi Priyatno (2009) ketentuannya adalah sebagai berikut:

a. Jika titik-titiknya membentuk pola tertentu yang teratur maka diindikasi-kan terdapat masalah heteroskedastisitas.

b. Jika tidak ada pola yang jelas, serta titik-titiknya menyebar di atas dan di bawah angka 0 pada sumbu $Y$, maka diindikasikan tidak terdapat masalah heterokedastisitas.

\section{Pengujian Hipotesis}

\section{Pengaruh Variabel Independent Terhadap Variabel Dependent}

Seperti dikemukakan pada rumusan masalah dan hipotesis penelitian yaitu menganalisis variabel Pengembangan Sumber Daya Manusia (X), sebagai variabel bebas (Independent Variabel) secara parsial, maka untuk menjelaskan didasarkan kepada analisis regresi linier sederhana seperti yang terlihat pada tabel berikut ini:

Tabel 7. Pengaruh Masing-masing Variabel Bebas Terhadap Variabel terkait

\begin{tabular}{|l|c|c|c|c|c|}
\hline \multicolumn{1}{|c|}{ Nama Variabel } & $\mathrm{B}$ & $\begin{array}{c}\text { Standar } \\
\text { Error }\end{array}$ & thitung & $\mathrm{t}_{\text {trabel }}$ & Sig \\
\hline Konstanta (a) & 3,511 & 0,645 & 5,442 & 2,032 & 0,000 \\
\hline Pengembangan SDM $(\mathrm{X})$ & 0,358 & 0,157 & 2,281 & 2,032 & 0,029 \\
\hline
\end{tabular}

Berdasarkan hasil output komputer melalui program SPSS, maka diperoleh persamaan regresi linier sederhana sebagai berikut :

$$
Y=3,511+0,358(X)
$$

Dari persamaan regresi di atas dapat dijelaskan hasil penelitian sebagai berikut :

\section{Koefisien Regresi ( $\beta$ )}

1. Koefisien konstanta sebesar 3,511 . Artinya bilamana variabel pengembangan sumber daya manusia $(X)$ dianggap konstan, maka besarnya kinerja dosen sebesar 3,511 dalam satuan skala Likert.

2. Besarnya koefisien variabel pengembangan sumber daya manusia sebesar 0,358 artinya setiap kenaikan $100 \%$ perubahan dalam variabel pengembangan sumber daya manusia secara relatif akan meningkatkan kinerja dosen sebesar $35,8 \%$.

Berdasarkan hasil analisis di atas dapat diketahui bahwa dari variabel yang diteliti, diketahui bahwa variabel, yaitu pengembangan sumber daya manusia $(X)$ mempunyai pengaruh yang sangat dominan terhadap kinerja dosen dalam meningkatkan visi dan misi Fakultas Ekonomi Universitas Serambi Mekkah.

\section{Koefisien korelasi (R) dan determinasi $\left(\mathbf{R}^{2}\right)$}

Sedangkan untuk melihat hubungan dan pengaruh variabel bebas terhadap kinerja dosen berdasarkan korelasi dan determinasi seperti dijelaskan pada tabel berikut ini :

Tabel 8. Model Summary

\begin{tabular}{|c|c|c|c|c|}
\hline$R$ & $\mathrm{R}^{2}$ & Adjusted $\mathrm{R}^{2}$ & $\begin{array}{c}\text { Std. Error of the } \\
\text { Estimate }\end{array}$ & Keterangan \\
\hline 0,364 & 0,133 & 0,107 &, 3187 & Korelasi cukup \\
\hline
\end{tabular}

Sumber : Data Primer, 2019 (diolah)

1. Koefisien korelasi $(R)=0,364$ yang menunjukkan bahwa derajat hubungan antara variabel bebas dengan variabel terikat sebesar $36,4 \%$. Artinya kinerja dosen dalam meningkatkan visi dan misi Fakultas Ekonomi 
Universitas Serambi Mekkah berkorelasi positif dengan korelasi yang cukup erat hubungannya dengan faktor pengembangan sumber daya manusia $(X)$.

2. Koefisien determinasi $\left(R^{2}\right)$ sebesar 0,133 . Artinya sebesar $13,3 \%$ perubahan-perubahan kinerja dosen dapat dijelaskan oleh perubahan dalam faktor pengembangan sumber daya manusia $(X)$, sedangkan selebihnya yaitu sebesar $86,7 \%$, dipengaruhi oleh faktor-faktor variabel lain di luar daripada yang menjadi variabel penelitian ini.

\section{Pengujian Secara Parsial (Uji-t)}

Uji parsial digunakan untuk menguji kemaknaan parsial variabel independen terhadap variabel dependen, pengambilan keputusan dilakukan dengan membandingkan nilai thitung dengan tabel, pada taraf signifikansi $\alpha=5 \%$. Hasil perhitungan yang diperlihatkan pada tabel 9 berikut ini:

Tabel 9. Uji Parsial (t-test)

\begin{tabular}{|c|l|r|r|}
\hline No & \multicolumn{1}{|c|}{ Variable Independen } & T & Sig. \\
\hline 1. & Pengembangan Sumber Daya Manusia $(X)$ & 2,281 & 0.029 \\
\hline
\end{tabular}

Sumber : Data Primer, 2019 (diolah)

Pada tabel di atas menunjukkan seberapa jauh faktor pengembangan sumber daya manusia $(X)$ mempengaruhi kinerja dosen $(Y)$ dalam meningkatkan visi dan misi Fakultas Ekonomi Universitas Serami Mekkah Banda Aceh. Hasil penelitian terhadap variabel pengembangan sumber daya manusia $(X)$ diperoleh $t_{\text {hitung }}(2,281)$ dan $t_{\text {tabel }}(2,032)$. Hasil perhitungan ini menunjukkan bahwa $t_{\text {hitung }}>t_{\text {tabel }}$ dengan signifikansi sebesar 0,029 atau probabilitas di bawah $a=5 \%$. Dengan demikian hasil perhitungan statistik menunjukkan bawa secara parsial variabel pengembangan sumber daya manusia berpengaruh secara signifikan terhadap kinerja dosen dalam meningkatkan visi dan misi Fakultas Ekonomi Universitas Serambi Mekkah Banda Aceh.

\section{PEMBAHASAN}

Analisis yang digunakan untuk pengujian hipotesis adalah dengan menggunakan analisis regresi linier sederhana. Berdasarkan hasil analisis regresi linier sederhana dengan menggunakan perhitungan program komputasi SPSS versi 20.0 diperoleh persamaan regresi:

$$
Y=3,511+0,358(X)
$$

Untuk menguji signifikansi dari persamaan regresi linier tersebut digunakan analisis varian untuk regresi. Berdasarkan hasil perhitungan diperoleh $t_{\text {hitung }}(2,281)$ dan $t_{\text {tabel }}(2,032)$. Hasil perhitungan ini menunjukkan bahwa $t_{\text {hitung }}>t_{\text {tabel }}$ dengan signifikansi sebesar 0,029 atau probabilitas di bawah $\alpha=5 \%$. Maka dapat disimpulkan bahwa persamaan regresi tersebut signifikan. Hubungan antara faktor pengembangan sumber daya manusia $(X)$ dengan kinerja dosen $(Y)$ dalam meningkatkan visi dan misi Fakultas Ekonomi Universitas Serambi Mekkah Banda Aceh, dapat diketahui dari harga koefesien korelasi. Berdasarkan hasil analisis dengan program komputasi SPSS versi 20.0 diperoleh koefesien korelasi atau $R$ sebesar 0,364 . Selanjutnya koefesien korelasi tersebut dapat diuji dengan menggunakan uji-t. Berdasarkan hasil uji-t variabel pengembangan sumber daya manusia berpengaruh terhadap kinerja dosen dalam meningkatkan visi dan misi Fakultas Ekonomi Universitas Serambi Mekkah Banda Aceh dimana nilai $t_{\text {hitung }}$ variabel tersebut lebih besar dari $t_{\text {tabel }}(2,032)$. Besarnya pengaruh atau kontribusi yang diberikan oleh pengaruh variabel pengembangan sumber daya manusia terhadap kinerja dosen dalam meningkatkan visi dan misi Fakultas Ekonomi Universitas Serambi Mekkah Banda Aceh dapat diketahui dari harga koefisien determinasi atau $R_{2}$ adjusted. Berdasarkan hasil perhitungan diperoleh harga $R^{2}=0,133$ yang berarti besarnya pengaruh pengembangan sumber daya manusia terhadap kinerja dosen dalam meningkatkan visi dan misi Fakultas Ekonomi Universitas Serambi Mekkah Banda Aceh adalah sebesar 13,3\%. Dari hasil tersebut menunjukkan bahwa selain variabel pengembangan sumber daya manusia, kinerja dosen dalam meningkatkan visi dan misi Fakultas Ekonomi Universitas Serambi Mekkah Banda Aceh juga dipengaruhi oleh variabel lain yang tidak dikaji dalam penelitian ini sebesar $86,7 \%$.

Hasil penelitian sejenis yang peneliti temui, yaitu penelitian yang dilakukan oleh Lilik Siswanta (2013), Endang Sukarjati, Maria Magdalena Manarsih dan Moh. Mukeri Warso (2016) dan Diah Rusminingsih (2010), juga menunjukkan adanya pengaruh yang signifikan dari pengaruh pengembangan sumber daya manusia, terhadap 
kinerja maupun produktivitas pegawai, dalam hal ini adalah kinerja dosen. Hasil penelitian di atas diperkuat oleh beberapa teori diantranya adalah pendapat yang dikemukakan Rowley (2012:88) yang mengatakan bahwa pengembangan sumber daya manusia adalah sebuah proses yang dilakukan untuk mengembangkan pengetahuan, keahlian, dan kemampuan pekerja, demikian juga dengan kompetensi-kompetensi yang dikembangkan melalui pelatihan dan pengembangan, pembelajaran organisasi, manajemen kepemimpinan, dan manajemen pengetahuan untuk kepentingan peningkatan kinerja. Sutrisno (2009), mengemukakan bahwa pengembangan sumber daya manusia tujuannya untuk meningkatkan kualitas profesionalisme dan keterampilan para karyawan dalam melaksanakan tugas dan fungsinya secara optimal. Dengan mengembangkan kecakapan karyawan dimaksudkan sebagai setiap usaha dari pemimpinan untuk menambah keahlian kerja tiap karayawan sehingga di dalam melaksanakan tugas-tugasnya dapat lebih efesien dan produktif. Oleh karena itu, organisasi perlu terus melakukan pengembangan sumber daya manusia karena investasi di dalam pengembangan sumber daya manusia merupakan pengeluaran yang ditunjukan untuk memperbaiki kapasitas produktif dari manusia.

\section{KESIMPULAN DAN SARAN}

\section{Kesimpulan}

Berdasarkan hasil penelitian dan pembahasan tentang pengaruh pengembangan sumber daya manusia terhadap kinerja dosen dalam meningkatkan visi dan misi Fakultas Ekonomi Universitas Serambi Mekkah Banda Aceh, maka dapat disimpulkan beberapa hal sebagai berikut :

Koefisien korelasi (R) sebesar 0,364 atau 36,4\%. Menandakan hubungan Linier positif dan berhubungan erat antara variabel bebas $(X)$ terhadap kinerja dosen dalam meningkatkan visi dan misi Fakultas Ekonomi Universitas Serambi Mekkah Banda Aceh. Koefisien determinasi ( $R^{2}$ adjusted) sebesar 0,133 yang artinya faktor pengembangan sumber daya manusia memiliki pengaruh terhadap kinerja dosen dalam meningkatkan visi dan misi Fakultas Ekonomi Universitas Serambi Mekkah Banda Aceh sebesar 13,3\%. Jadi perubahan faktor kinerja dosen dalam meningkatkan visi dan misi Fakultas Ekonomi Universitas Serambi Mekkah Banda Aceh akan dipengaruhi faktor lain selain faktor-faktor tersebut sebesar $86,7 \%$. Hasil Uji t yang menandakan besarnya tingkat pengaruh dari variabel pengembangan sumber daya manusia terhadap kinerja dosen dalam meningkatkan visi dan misi Fakultas Ekonomi Universitas Serambi Mekkah Banda Aceh, hal ini dikarenakan variabel X tersebut memiliki thitung yang lebih besar dari tabel.

\section{Saran}

Berdasarkan kesimpulan di atas, maka peneliti memberikan beberapa saran sebagai berikut:

1. Kepada pihak pimpinan hendaknya mempertahankan konsep kontrolling sumber daya manusia yang sudah diterapkan, sekaligus dengan meningkatkan pengendalian mutu dosen, agar kualitas sumber daya manusia para dosen semakin meningkat.

3. Kepada para dosen hendaknya meningkatkan totalitas dalam bekerja dengan mengikuti aturan-aturan yang diterapkan pimpinan atau lembaga, agar bisa memaksimalkan kualitas sumber daya yang dimiliki, sehingga bisa meningkatkan produktivitas keja, khususnya dalam memajukan visi dan misi Fakultas.

4. Bagi peneliti lain, diharapkan untuk dapat meneruskan dan mengembangkan penelitian ini pada masa yang akan datang dengan lebih komprehensif, melalui penelitian yang lebih mendalam tentang faktor-faktor lain yang mempengaruhi kinerja dosen. Dikarenakan variabel bebas atau faktor pengembangan sumber daya manusia dalam penelitian ini belum mampu menjelaskan pengaruhnya terhadap variabel terikat di atas $90 \%$, penelitian ini hanya mampu menjelaskan pengaruhnya terhadap variabel terikat sebesar $36,4 \%$. Karena variabel independent dalam penelitian ini hanya 1 saja, sehingga perlu ditambahkan variabel lain yang sesuai, seperti pemberian insentif, gizi dan kesehatan, serta kondisi lingkungan sosial budaya dan faktor-faktor lainlain yang dianggap sesuai untuk mempengaruhi kinerja dosen.. 


\section{REFERENSI}

Chris Rowley dan Keith Jackson. 2012. Manajemen Sumber Daya Manusia The Key Concepts, Cetakan Kesatu, PT Rajagrafindo Persada, Jakarta.

Depertemen Pendidikan Nasional RI, Pedoman Beban Kerja Dosen Dan Evaluasi Pelaksanaan Tridharma Tinggi (Jakarta: Direktorat Jenderal Pendidikan Tinggi, 2010),hlm 1.

Dessler, Gary. 2010. Manajemen Sumber Daya Manusia (edisi kesepuluh). Jakarta Barat: PT Indeks.

Dessler, Gary. 2013. Manajemen Sumber Daya Manusia Human Reources, jilid 2, Prenhalindo, Jakarta

Ghozali, Imam. 2011. Aplikasi Analisis Multivariate dengan Program SPPS. Semarang: Universitas Diponegoro.

Hamid, Abdul. 2010. Panduan Penulisan Skripsi. Cetakan 1. Jakarta: FEIS UIN Pres.

Handoko, T. Hani. 2011. Manajemen personalia dan sumber daya manusia. Edisi 2. BPFE. Yogyakarta.

Hasibuan, Malayu S. P. 2000. Manajemen Sumber Daya Manusia. Edisi. Revisi. Jakarta: PT Bumi Aksara.

Hasibuan, Malayu S. P .2008. Manajemen Sumber Daya Manusia. Jakarta, PT. Bumi Aksara.

Husnan H. S. 1990. Manajemen Personalia. Yogyakarta. BFFE.

Malhotra, Naresh K, 2015. Riset Pemasaran: Pendekatan Terapan, Alih Bahasa. Rusyadi Maryam, Edisi. Keempat, Jakarta: Indeks

Mangkunegara, Anwar Prabu. 2009. Manajemen Sumber Daya Manusia Perusahaan. Bandung: PT Remaja Rosda Karya.

Mangkunegara, Anwar Prabu. 2011. Evaluasi Kinerja Sumber Daya Manusia. Bandung: Rafika Aditama.

Nawawi, Hidari. 2012. Metode Penelitian Bidang Sosial. Yogyakarta: Gajah Mada University Press.

Notoatmodjo, S. 2010. Metodologi Penelitian Kesehatan. Rineka Cipta: Jakarta.

Priyatno Duwi. 2012. Cara Kilat Belajar Analisis Data Dengan SPSS 20. Yogyakarta:Andi.

Rivai, Veithezal, Sagala, Ella Jauvani. 2009. Manajemen Sumber Daya Manusia untuk Perusahaan dari Teori ke Pratik. Jakarta:PT Raja Grafindo.

Santoso, Singgih. 2007. Statistik Deskriptif: Konsep dan Aplikasi dengan Microsoft Exel dan SPPS. ANDI: Yogyakarta.

Singodimedjo, Markum. 2000. Manajemen Sumber Daya Manusia. Surabaya: SMMAS.

Sisdiknas.2005. Himpunan Per Undangan - Undangan Guru Dan Dosen. Fokusmedia. Bandung.

Siswata, lilik. 2013. Upaya Peningkatan Kinerja Dosen Dalam Pengembangan Sumber Daya Manusia Untuk Mendukung Visi dan Misi UPY. Akmenika. E-Jurnal Akuntasi dan Manajemen, Universitas PGRI Yogyakarta:241-305.

Soekidjo, Notoadmodjo. 1992. Pengembangan Sumnber Daya Manusia, Jakarta, Rineka Cipta. 
Sugiyono. 2012. Metode Peneletian Kunatitatif Kualitatif dan R\&D. Bandung: Alfabeta.

Sugiyono. 2004. Metodologi Penelitian Pendidikan. Pendekatan Kuantitatif, Kualitatif, dan R\&D. Alfabeta. Bandung.

Suprihatiningrum. 2013. Guru Profesional. Pendoman Kinerja, Kualifikasi, \& Kompetensi Guru. Jogjakarta: Ar-Ruzz Media, hal 136.

Sutadji, S.Fi, 2010. Perecanaan dan Pengembangan Sumber Daya Manusia.Yogyakarta: Dee Publish.

Sutrino, Edy. 2009. Manajemen Sumber Daya Manusia. PRENADAMEDIA GROUP :Jakarta.

Usman, Nasir. 2007. Manajemen Peningkatan Kinerja Guru. Bandung: Mutiara IImu, hal 109.

Wibowo. 2009. Manajemen Kinerja. Edisi kedua, Jakarta: Rajawali Pers, hal 7.

Yunus, Eddy. 2016. Manajemen Strategis. Ed. I. - Yogyakarta: Andi. CV. ANDI OFFSET 